\title{
Introduction of Dual Education in Ukrainian Higher Educational Establishments and Approaches to Estimation of its Economic Benefits
}

\author{
Gregory Rayter \\ MBA, RAYTER INC., Dallas, TX USA \\ Olena Davlikanova
}

Project Coordinator, Friedrich Ebert Foundation, Ukraine

\begin{abstract}
The article describes current state of dual education introduction in Ukraine. This model aims at deepening cooperation of educational institutions and employers, as well as advancing youth economic competitiveness in the changing due to 4.0 Industry labor market. The main characteristics and advantages of dual programs are presented. International approaches to costing economic benefits of dual programs for the parties that can be integrated into Ukrainian practices are also outlined.
\end{abstract}

Keywords: dual education, benefits, costs, cooperation between educational institutions and employers.

JEL Classification: I21, D61, E24.

(C) The Authors, 2017. This article is published with open access at ARMG Publishing.

Introduction: Problem statement in general terms and its connection to important scientific and practical objectives

The quality of personnel training is one of the key factors influencing national economy. The nature of decisions made at each level, hence companies' revenues, the volume of taxes paid into the national budget, the rate of innovation development, the efficiency of management decisions in the public sector, quality of services and the level of life as a whole, depend on qualifications and soft skills of economically active population.

The lack of systematic cooperation between higher education institutions (HEI) and employers leads to a gap between the expectations of the latter and the qualifications of graduates. This statement has been confirmed by a number of studies, such as "Experience of graduates' employment: the view of graduates and employers"1 and "Identifying and solving the problem of skills gap in Ukraine".

The education content modernization does not keep pace with the needs of Ukrainian economy, although its updating and the establishment of close cooperation between educational institutions and employers are among the priorities of the current reform of higher education. It becomes even more topical with regard to the worldwide trends like globalization and shift to the knowledge-based economy. Rapid development of technologies vanishes layers of professions and work places demanding advanced knowledge and skills of labor force and still not guaranteeing employment. As of direct HEIs' concerns, today students have wider than ever possibilities to get education in any University worldwide due to online education and advancement of students' mobility, on one hand. On the other hand, some of the knowledge gained during the first year of studies becomes out-dated before students even graduate, so educational institutions can not afford to ignore the necessity to adapt to challenges set by the new times.

One of the ways to meet challenges and achieve the above-mentioned priorities of educational reform may be the adaptation of international experience and integration of dual model into the higher education system of Ukraine.

\footnotetext{
1"Experience of graduates' employment: view of graduates and employers", research. - Available at: http://www.mlsp.gov.ua/labour/control/uk/publish/article\%3Bjsessionid=B9C5A78F677E5C203472FD56685D549A.app1 ?art_id= $176359 \&$ cat id=107177.

2 https://www.oecd.org/globalrelations/Skills_Gap_Assessment_Ukraine_UKR.pdf
} 
Setting the aim of the article. The aim of this article is to review the current state of dual education introduction in Ukraine and present general overview of international practices in calculating costs and benefits of dual education programs.

\section{Analysis of key publications and studies}

Today, the issue of dual education model integration into Ukrainian education system is poorly studied, although the system itself and its benefits to the EU countries and the USA are described in detail in many publications by not only foreign but also Ukrainian scholars and practitioners. Ulrich Mill describes approaches to the organization of dual education in Germany, the rights and responsibilities of the parties, and stresses the need to maintain constant contact between a student, an educational institution and an employer. Helmut Hofstetter outlines basic requirements to the design of dual programs and the organization of the educational process based on the example of German Universities. Diane-Gabrielle Tremblay and Irène Le Bot studied evolution of dual education system in Germany and arising challenges as of 2003. Aaron S. Horn, Leah Reinert and Sung Tae Jang analyze the activities of state and regional accreditation agencies and their ability to ensure and verify the quality of dual programs. M. Dernova looks into practical application of the dual model in higher professional education of adults in European countries. Davlikanova O., Kupenko O., Svitailo N. speak about the Ukrainian experience of organizational and pedagogical support for the implementation of dual education model elements into the system of higher education in Ukraine.

\section{Description of previously unresolved aspects of the issue addressed by this article}

Despite a large number of studies describing the system of dual education and its benefits for the EU countries and the USA, Ukrainian experience has hardly been described, and no tool to calculate costs and benefits of dual programs has been offered to HEIs and employers.

\section{Presentation of the core study with broad justification of the received scientific results}

A combined training at an educational institution and an enterprise, state institution or organization is not a complete novelty to Ukraine. However, after the collapse of the Soviet Union, elimination of central planning, privatization, emergence of new industries and professions, as well as autonomization of Universities have significantly changed the "playing field". All these factors require rethinking the Ukrainian educational institutions' activities in the international market of educational services.

Moreover, some trends in the development of the Ukrainian education system should be taken into account. For example, working professions and VET are significantly losing its attractiveness and prestige. Hence, the demand for higher education is growing, while its quality in some cases does not withstand criticism. According to the data of the information-analytical center Info-Light ${ }^{3}$ since 2003, there has been a steady decline in the number of education applicants to technical schools or colleges by almost 37 percent. As of 2016-2017 academic year 217.3 and 1369.4 thousand people study in the HEIs of I-II and III-IV levels of accreditation accordingly.

At the same time, there is an increase in the number of Ukrainians leaving to study abroad. According to the CEDOS $^{4}$ think-tank since 2009 the number of such students increased by 129\% and as of 2014/2015 academic year 59,648 Ukrainian citizens study at universities in the EU, Canada and the USA.

Therefore, modernization of approaches to students' education and training by means of the best international practices introduction, including dual education, is becoming vital for competitiveness of Ukrainian educational establishments.

In Germany, which is considered to be the founder of dual education and its main exporter overseas, the tradition of public-private partnership and well-established model of cooperation between all the parties engaged in dual education ensure its popularity. First, it emerged as a response to the needs of VET. Still, in

\footnotetext{
3"Experience of graduates' employment: view of graduates and employers", research. - Available at: http://www.mlsp.gov.ua/labour/control/uk/publish/article\%3Bjsessionid=B9C5A78F677E5C203472FD56685D549A.app1 ?art_id=1 76359\&cat id $=107177$.

4"Experience of graduates' employment: view of graduates and employers”, research. - Available at: http://www.mlsp.gov.ua/labour/control/uk/publish/article\%3Bjsessionid=B9C5A78F677E5C203472FD56685D549A.app1?art_id=1 $\underline{76359 \& \text { cat_id }=107177 .}$.
} 
1972 Bosch, Daimler Benz (today Daimler-Chrysler) and Standard Elektrik Lorenz (SEL) set an initiative to adapt dual education model to training of applied sciences university students. It was due to the need in welleducated staff with high-level professional skills that classical universities could not satisfy. ${ }^{5}$

Today, 1,563 dual study programs are offered by higher education institutions in Germany.

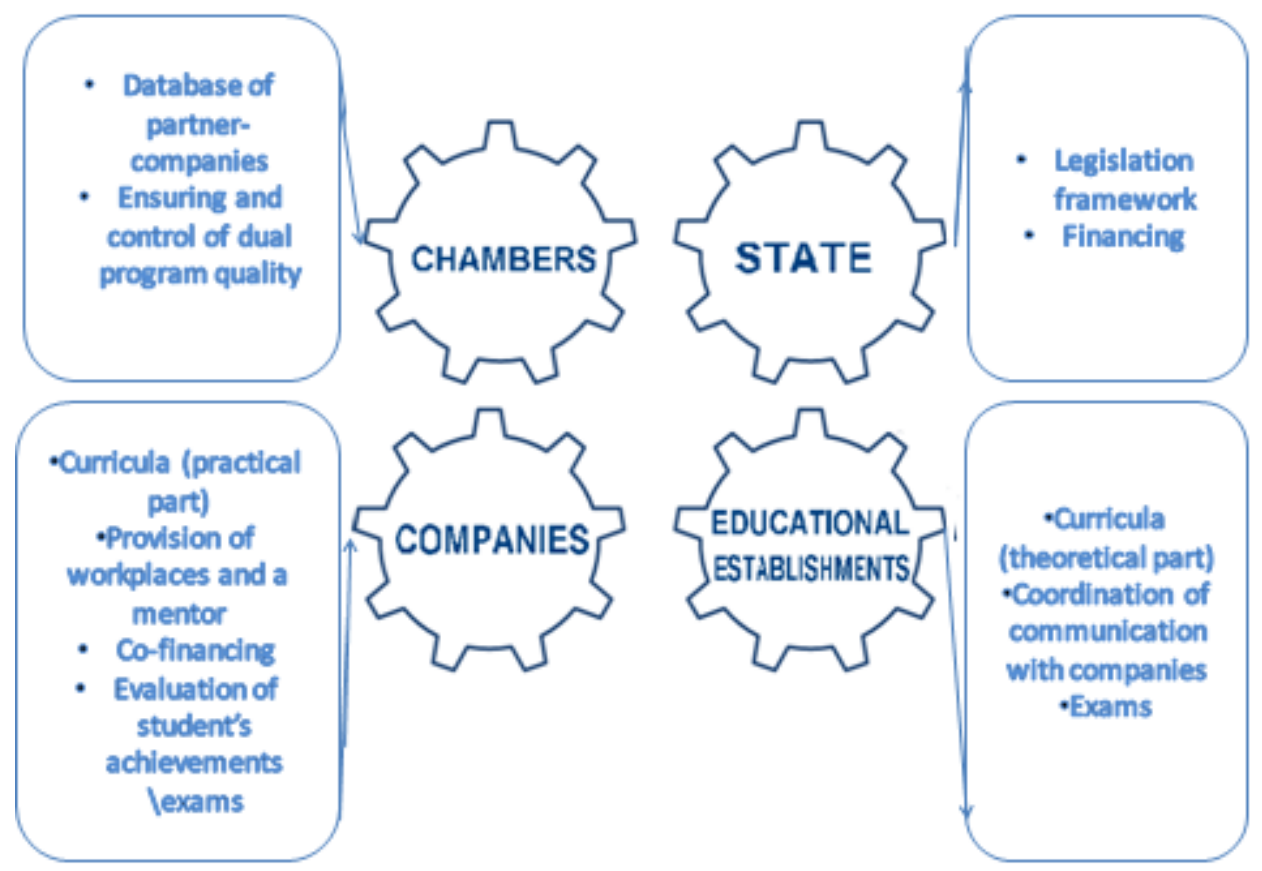

Figure 1. Interaction of parties in the organization of dual education in Germany.

In Ukraine, cooperation of employers and some higher educational institutions training specialists for the production and agrarian sector was preserved after 1991. It is also well developed in IT. However, the term "dual education" ("dual form of education") was first defined at the legislative level in the Law of Ukraine No. 2145-VIII "On Education”, adopted by the Verkhovna Rada of Ukraine on September 5, 2017.

Impossibility to blindly copy the German system has been widely discussed by many EU countries. ${ }^{6}$ It is unworkable to adopt any model without adaptation not only to the legislative field, but also to realities such as the state of national economy in general and industries in particular, traditions of self-organization of employers, priorities and performance of Chambers of Commerce, level of corporate social responsibility, openness of educational institutions and their ability to focus on rapid changes in the labor market and in educational trends. For example, a large number of the specializations acquired in Germany within VET is offered in Ukraine by higher education institutions.

On top of that, according to the European Commission in the view of Industry 4.0 it is expected that by 2025 nearly $50 \%$ of all job openings on the European labor market will require tertiary qualifications. "This calls for a higher education sector that trains researchers to solve modernday problems and equips graduates with an entrepreneurial mindset and drive. To succeed, higher education institutions need to be more innovative and relevant in an increasingly globalised, digitalised and knowledge-dependent labour market. The need to enhance the match between higher education and the skills requirements of the modern economy is underlined in some of the 2016 European Semester country-specific recommendations to Member States. One of the means to increase the relevance of programs is to embed work-based learning, a common component of vocational education and training, across higher education. Evidence shows that students who have participated in

\footnotetext{
${ }^{5}$ Göhringer A. University of Cooperative Education - Karlsruhe: The Dual System of Higher Education in Germany, Asia Pacific Journal of Cooperative Education / A. Göhringer. - 2002 - 3 (2) - S. 53-58

${ }^{6}$ Tremblay, Diane-Gabrielle, Le Bot, Irène (2003). German system of dual training: analysis of evolution and modern challenges.
} 
practical training before graduation are more likely to find jobs than their counterparts without relevant work experience". ${ }^{7}$

With regard to all the abovementioned in 2013 Friedrich-Ebert-Stiftung (Foundation) Office in Ukraine (FES) in partnership with the Ukrainian Marketing Association launched the project "Introduction of dual education system elements into practices of Ukrainian HEIs for increasing competitiveness of graduates in the labor market". Within the framework of the project the first national-level event in Ukraine devoted exclusively to dual education was held - the International scientific and practical conference "Dual education as a response to the challenges faced by the modern system of Ukrainian education". It was supported by Lilia Grynevych, who was then the Chairman of Parliamentary Committee on science and education. The conference took place on September 18-19, 2014 at the National Technical University "Kyiv Polytechnic Institute" and was marked by the development of the "Roadmap for the implementation of dual education in Ukraine" as well as idea to draft the Concept of Dual Education for Ukrainian higher educational establishments. After that, a campaign was launched to promote German model of dual education among all stakeholders - universities, employers, trade unions, think tanks, HRs, with the involvement of the Ministry of Education and Science of Ukraine, the Ministry of Social Policy and the Ministry of Youth and Sport.

In 2016, FES and a number of HEIs signed memoranda of cooperation to test elements of the dual model and adapt it to both Ukrainian legislation and realities.

\begin{tabular}{|l|l|}
\hline \multicolumn{2}{|c|}{ List of HEIs participating in the project } \\
\hline $\begin{array}{l}\text { Donbas National Academy of Civil Engineering and } \\
\text { Architecture }\end{array}$ & $\begin{array}{l}\text { Construction management. Housing and public services } \\
\text { management. }\end{array}$ \\
\hline Luhansk National Agrarian University & Construction and civil engineering \\
\hline Ukrainian National Forestry University (Lviv) & $\begin{array}{l}\text { Woodworking technologies } \\
\text { Wood processing technologies }\end{array}$ \\
\hline National Mining University & Marketing \\
\hline National Transport University & Automobile transport \\
\hline Sumy State University & Social work \\
\hline $\begin{array}{l}\text { National Aerospace University KhAI named after M. } \\
\text { Zhukovskii }\end{array}$ & Automotive transport \\
\hline $\begin{array}{l}\text { Kharkiv National University of Urban Economy n.a. } \\
\text { O. Beketov }\end{array}$ & Electrical engineering and electromechanics \\
\hline $\begin{array}{l}\text { Kharkiv State University of Food Technology and } \\
\text { Trade }\end{array}$ & Food Technology \\
\hline Khmelnytskyi National University & Entrepreneurship, trade, stock market activity, marketing \\
\hline
\end{tabular}

In the process of pilot design and implementation of dual programs, many questions arose. Some of them were answered through trial and error. Yet, some remain open. Nevertheless, such a wide scope of experiences with regard to the regional economic differences and a variety of chosen specializations provided sufficient material for the Dual Education Concept for Ukrainian HEIs. The aim of the Concept is to popularize the model by a wider explanation of its definition given in the Law and present general guidelines for dual education introduction.

In addition to activities aimed at attracting HEIs of III-IV level of accreditation to launch pilot projects, cooperation with the Federation of Employers of Ukraine was established, which was focused on dual education in VET at the time.

On February 13, 2017 at the meeting of FES and dual education project partners with Lilia Grynevych, the Minister of Education of Ukraine, it was agreed to create a working group at the Ministry of Education and Science of Ukraine in order to help educational institutions find solutions to arising issues while implementing dual education. The Federation of Employers of Ukraine also supported the idea and joined the working group, where in discussions the idea of drafting the Dual Education Concept came up again. Four versions were presented. The first one was an updated 2014 draft of the Concept, mainly compiled by the Head of the Coordination Center for Humanitarian Policy of Sumy State University N.Svitailo, the Director of the Ukrainian Marketing Association I.Lylyk and FES project coordinator O.Davlikanova. Another version was developed under the supervision of the director of the "Scientific and Methodological Center for Information

7 Education and Training Monitor 2016. European Commission Available at: http://ec.europa.eu/education/sites/education/files/monitor2016_en.pdf 
and Analytical Support of Higher Educational Institutions "Agro-Education" T.Ishchenko. The third one was sent by the Ukrainian National Forestry University (NFU). This text was written by the NFU Vice-Rector for scientific and pedagogical activities and international relations M.Borys, Head of the NFU Department of International Relations O.Vrublevska and Head of the Association of NFU Graduates O.Prysta. The fourth version was developed under supervision of T.Reshetilova, Head of the Department of the National Mining University. All texts were discussed at the meetings of the working group and compiled into a unified document. In the process it was decided to change the title "The Dual Education Concept for Ukrainian Higher Educational Institutions" to "The Dual Education Concept for Educational Institutions in Ukriane". A significant contribution was made by the Deputy Minister V.Kovtunets and the Head of the Higher Education Department at the Ministry of Education and Science of Ukraine O.Sharov. At present, the draft Concept is available at the Ministry Education and Science website for public discussion. ${ }^{8}$ Its adoption is expected at the Board of Rectors on December 14, 2017.

Three key indicators for defining the form of education as dual have been identified:

$>$ the scope of the on-the-job (work-based) training is no less than $30 \%$ of the program;

$>$ employers take part in the development of a dual program as well as in its implementation, selection of dual students and in the assessment of their achievements;

$>$ training is carried out in the framework of special agreements signed between an educational institution and an employer. An employment contract may be offered to a dual student by an employer.

The employment contract remains a stumbling block as on one hand no economic stimuli with regard to dual education are yet foreseen for employers in the legislation, on the other hand not all medium or small firms as well as state institutions that might provide sufficient on-the-job training can offer such a contract both due to financial or bureaucratic reasons.

In addition to the described above activities, other projects and initiatives relevant to dual education have been implemented in Ukraine. They also should be mentioned, even though none of them was aiming at establishing a systematic approach to the dual education introduction for both technical and humanitarian specializations (where applicable), or popularization and adaptation of dual education to the Ukrainian context (legislation, state of the economy, ways of educational institutions' operation, underdeveloped culture of social responsibility of enterprises, or poor coordination of various associations of employers).

In particular, an American investment company RAYTER INC. and Ukrainian system integrator BMS Consulting promoted a typical bachelor's program for "Cyber Security", which was developed in accordance with the international professional standard CISSP (Certified Information Systems Security Professional) and with regard to the requirements of the educational standard of Ukraine for specialization 125 "Cyber Security". The program ensures acquisition of specific professional competences and can be introduced by Ukrainian universities in the 3rd and 4th year of study.

In partnership with Duale Hochschule Gera-Eisenach a one-year project "Dual Education in Dialogue" was implemented in 2017 at the Faculty of Computer Science and Cybernetics of Taras Shevchenko National University in the framework of the Eastern Partnership program aimed at acknowledgment of Ukrainian stakeholders with German dual education practices.

In October 2016 a trip "Dual Education for Agriculture - German Experience and Recommendations for Ukraine" was organized for Ukrainian teachers, employers and civil servants as part of the German-Ukrainian Agri-Policy Dialogue.

Kharkiv Computer and Technological College of the National Technical University "Kharkiv Polytechnic Institute" introduced an experimental training of students starting September 1, 2014 on the principles of dual education.

This article does not aim at listing all initiatives concerning the experimental implementation of dual education, however, it is worth mentioning the cooperation with employers of Kharkiv Aviation University, National Technical University of Ukraine "Kyiv Polytechnic Institute", National Transport University and the initiative within the Pact for Youth-2020 signed on March 17, 2016, which is supported by the Ministry of Youth and Sport of Ukraine and is being implemented within the European Pact for Youth.

\footnotetext{
8 Draft of Dual Education Concept:_http://mon.gov.ua/usi-novivni/povidomlennya/2017/11/21/v-rozdili-gromadske-obgovorennya-rozmishhenoproekt-konczepcziyi-pidgotovki-faxivcziv-za-dual/
} 
Nevertheless, as the first Deputy Minister of Education, V.Kovtunets has rightly noted: "We are still on our way to actual introduction of dual education". 9 After the adoption of the Concept a number of issues regarding organization and legislative regulation will be solved. However, the discussion on estimation of dual education costs and benefits should be launched already.

Despite the fact that dual education in Ukraine is at its early stage of development, the costing of its economic efficiency for HEIs and employers is relevant in several respects. Firstly, as for any investment project, it is important to foresee outcomes and calculate a breakeven point. Secondly, when making a decision on ensuring an on-the-job training, an employer should estimate associated operational costs and may compare them to the operational costs of standard selection and recruiting procedures. Some expenditure is not subject to direct costing; still they might be estimated in percentage.

Educational establishments should take into account the following:

1. Cost items at the start of the program:

$>$ marketing research;

$>$ program coordinator(s) salary;

$>$ costs for promo-materials development, print and advertising;

$>$ renovation of premises (open office);

$>$ furniture and office equipment;

$>$ software;

$>$ costs for developing the database of students and employers;

$>$ consumables;

$>$ costs of training for university staff engaged in dual program development and facilitation.

others.

2. Program facilitation cost items:

salaries of administrative and technical staff;

$>$ business trips (involving employers and visiting places of training);

operational costs (consumables, telephone, postage, etc.);

$>$ costs for professional development (conferences, seminars);

$>$ expenses on improvements advised by employers;

$>$ advertising and program promotion costs;

$>$ reference and printed materials;

$>$ others.

3. Number of personnel and workload:

$>$ typical dual programs range from 100 to 1000 students' on-the-job training arrangements per year;

$>$ one dual program coordinator can control from 100 to 300 of such arrangements per year;

$>$ if coordinator is responsible for preparing students for apprenticeship, expansion of employers' database, selection of the best matching options for students and employers, visiting places of apprenticeship and assessment of students' achievements, then with the support of technical staff he/she can cover no more than 100-140 arrangements.

Costing may also depend on the organizational model of dual education unit/department in HEI, as each model provides a different number of employees/hours covered within expenses on a dual program. Here are examples of such models ${ }^{10}$ :

\footnotetext{
${ }^{9}$ http://fru.ua/ua/events/dualna-vyshcha-osvita-v-ukraini-iak-zastosuvaty-dosvid-nimechchyny

${ }^{10}$ Co-operative Education Manual A Guide to Planning and Implementing Co-operative Education Programs in Post-Secondary Institutions. Published by Canadian Association for Co-operative Education. 2005, Toronto, Ontario, Canada p. 45. 


\section{Centralized DE Model}

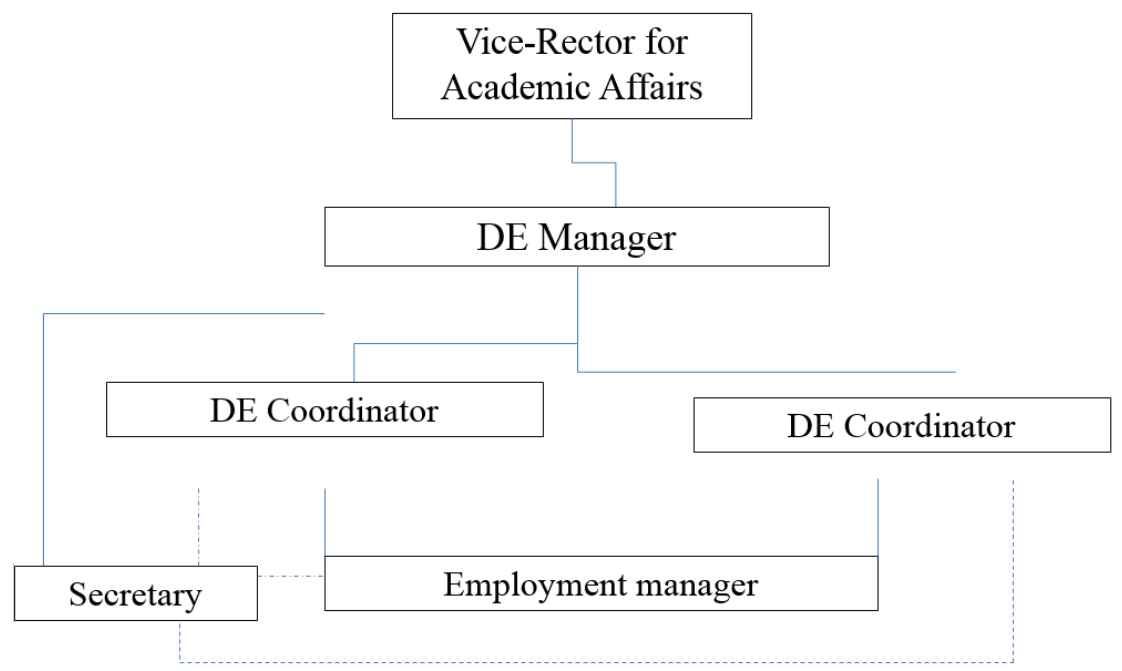

Figure 2. Centralized model of Dual Program Management in HEI

This approach allows avoiding duplication of functions; eases control over the quality and consistency of dual programs; ensures the unity of policies and procedures: contributes to effective establishment and maintenance of contacts with employers; allows to reduce operating costs on program management; ensures enrollment of a large number of students in dual programs; involves a single budget. As for the disadvantages, one can name less interaction with teachers in comparison to the decentralized approach, as well as the need for additional efforts from the dual education unit to control the quality of teachers' activities and their understanding and support for the idea as such.

\section{Decentralized DE Model}

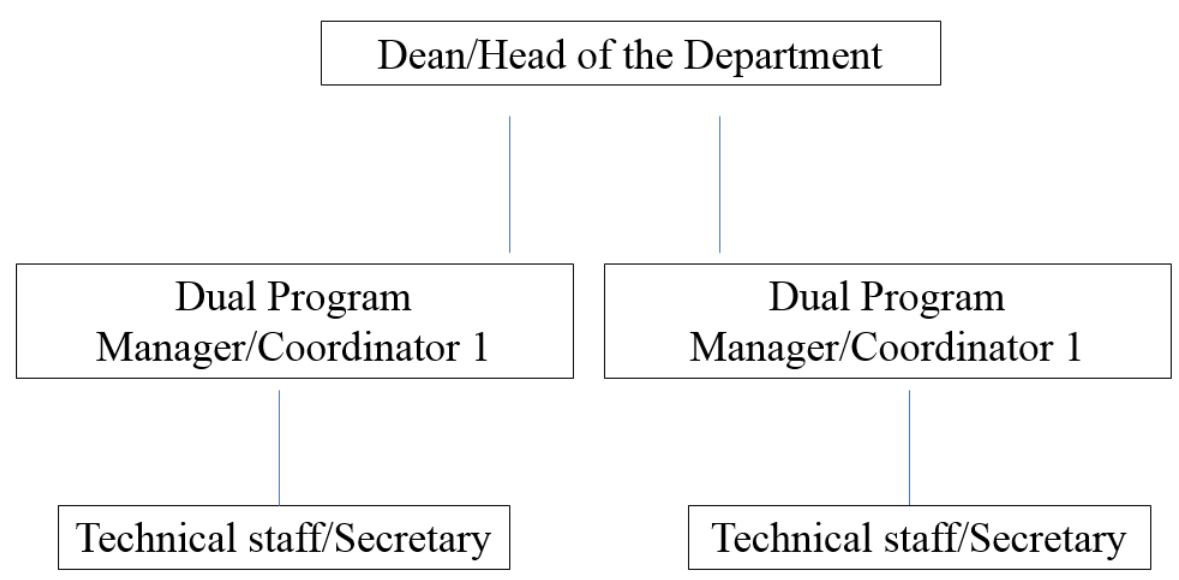

Figure 3. Decentralized model of Dual Program Management in HEI.

This approach ensures close contact between teachers and administration involved in dual education management, as well as between administrative staff and students. It allows better acknowledgement of administration with curriculum and deep integration with academic units. Teachers are engaged into visiting employers, assessment of students' reports, and, as a consequence, they come to a better understanding of the program relevance to the needs of employers. The closer is the communication with employers, the more stimuli there are for teachers' professional growth, as they get information on resent practices and developments in the field. Concerning shortcomings, it should be noted that this model is more expensive for HEI. There is a high chance that divergent standards, policies and procedures will be developed and applied in the framework of different dual programs. In addition, it is characterized by the lack of coordination and centralized lobbying of dual programs; and a low student/dual program staff ratio. 


\section{Mixed DE Model}

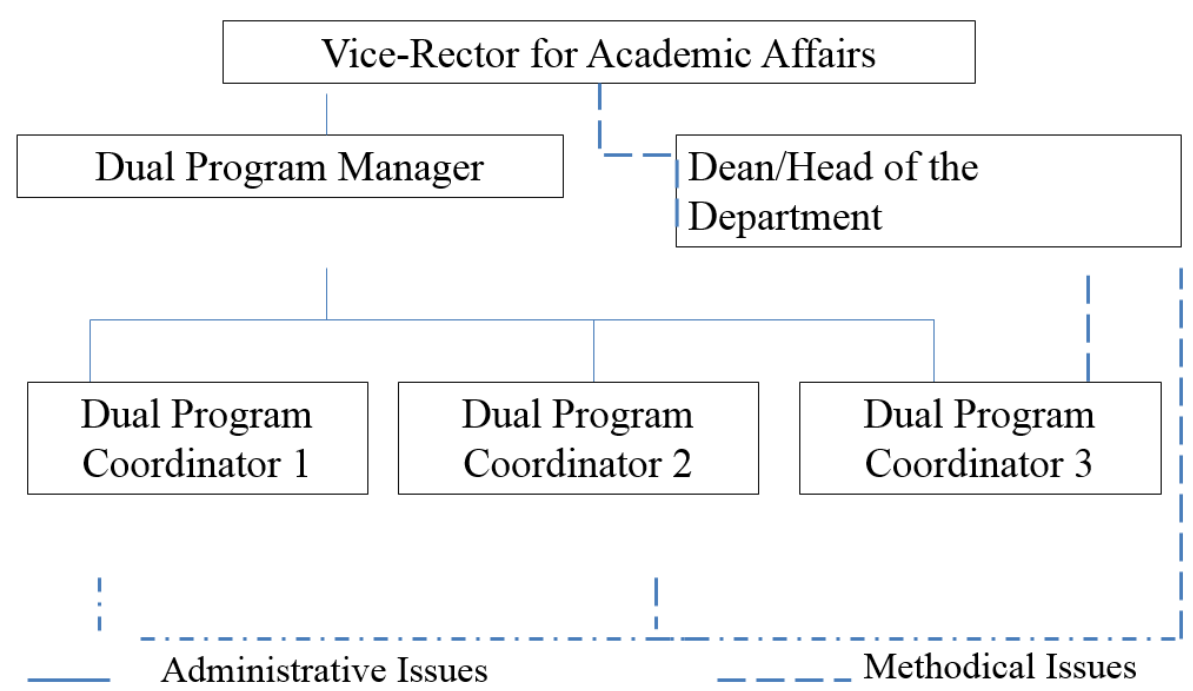

Figure 4. Mixed model of Dual Program Management in HEI.

This model combines all the advantages and disadvantages of previous approaches. Its main features are a combination of centralized administrative management and decentralized academic staff; clear guidance and transparent communication system due to double-subordination; more complex process of achieving operational consensus - a shared vision of dual programs implementation.

Educational establishment also have an option to establish a separate project office to coordinate dual programs.

\section{Revenue sources:}

$>$ tuition fees ${ }^{11}$. More work-based hours free seminar rooms which allows to enroll a higher number of students and, accordingly, to increase revenues due to tuitions. Moreover, well-developed and advertised dual programs may enlarge the number of HEI applicants as such;

$>$ payment for participation in the dual program (covers administrative costs and ranges from 25 to $80 \%$ of the budget depending on the university policy);

state budget financing.

The employer's costs are mainly be related to the size of payments to employees involved in the program, as well as the wages of students. These costs may be compared to the cost of traditional ways of selection and recruitment of young professionals. Taking into account the current economic situation in Ukraine, this comparison may not be in favor of the dual program, and when "selling" the program to an employer, it is expedient to use indirect benefits for the employer - such as the speed of adaptation of a future possible employee, quaranteed suitable qualifications, etc.

\section{Conclusions and prospects of further study}

Thus, as of today favorable conditions for the introduction of dual education not only in VET, but also in HEIs have already been created in Ukraine. After the expected adoption of the Dual Education Concept, further steps are to be taken to advance legislation, develop methodological recommendations, and most importantly, increase the number of Ukrainian practices. The number of international projects and initiatives of Ukrainian educational establishments has significantly increased compared to 2013, when the first project on the subject "Implementation of elements of the system of dual education in higher educational institutions of Ukraine in order to increase the competitiveness of graduates in the labor market" was launched by Friedrich-EbertStiftung. After the settlement of legislative and administrative issues and accumulation of Ukrainian experience, the issue of dual program costing and methods of evaluation of HEI-employers' cooperation effectiveness will become topical.

\footnotetext{
${ }^{11}$ This abstact is relevant to non-German models, where education is free for students.
} 
The prospect of further research is the development of approaches to the economic justification of the effectiveness of dual programs.

\section{References}

1. Co-operative Education Manual: A Guide to Planning and Implementing Co-operative Education Programs in Post-Secondary Institutions. (2005). Published by Canadian Association for Co-operative Education. Toronto, Ontario, Canada p. 45.

2. Davlikanova, O., Kupenko, O., Svitailo, N. (2017). Dosvid orhanizatsiynoho ta pedahohichnoyi pidtrymky vprovadzhennya elementiv dual'noyi osvity (na prykladi Sums'koho derzhavnoho universytetu) [Experience of organizational and pedagogical support for the implementation of elements of dual education (by the example of Sumy State University)], 17(1). Available at: http://uam.in.ua/rus/projects/marketing-inua/arhive.php.

3. Dernova, M. G. (2014). Dual'na model' vyshchoyi profesiynoyi osvity doroslykh: yevropeys'kyy dosvid [Dual model of higher professional education for adults: European experience]. Adult education: theory, experience, perspectives, 2, 137-145. Available at: http://nbuv.gov.ua/UJRN/OD_2014_2_19.

4. Education and Training Monitor 2016. European Commission. Available at: http://ec.europa.eu/education/sites/education/files/monitor2016 en.pdf.

5. "Experience of graduates' employment: view of graduates and employers", research. - Available at: http://www.mlsp.gov.ua/labour/control/uk/publish/article\%3Bjsessionid=B9C5A78F677E5C203472FD5 6685D549A.app1?art id=176359\&cat id=107177.

6. Göhringer, A. (2002). University of Cooperative Education - Karlsruhe: The Dual System of Higher Education in Germany, Asia Pacific Journal of Cooperative Education, 3(2), 53-58.

7. Horn, Aaron S., Reinert, Leah, and Jang, Sung Tae (2016). Policy and strategies of the faculty related to the acquiring qualifications within the framework of dual programs: analysis of the activities of state and regional accreditation agencies. Available at: https://www.ecs.org/ec-content/uploads/FacultyQualification-Policies-and-Strategies-Relevant-to-Dual-Enrollment-Programs-An-Analysis-of-States-andRegional-Accreditation-Agencies-2.pdf.

8. Mill, U. (2017). Dual education: experience of Germany. Marketing in Ukraine Journal, 17(1). Available at: http://uam.in.ua/rus/projects/marketing-in-ua/arhive.php.

9. Official site of the Information and Analytical Center Info-Light. Available at: http://infolight.org.ua/amcharts/dynamika-studentiv-u-vnz-i-iv-rivnya-akredytaciyi1990-2017-rokah.

10. Official site of the Ministry of Education and Science of Ukraine. Available at: http://mon.gov.ua/usinovivni/povidomlennya/2017/02/22/pri-mon-praczyuvatime-robocha-grupa-z-uprovadzhennya-dualnoyiosviti-u-vishhu-shkolu-ukrayini/.

11.Official site of the Organisation for Economic Co-operation and Development (OECD) (2015). Report "Identifying and solving the problem of skills gap in Ukraine". Available at: https://www.oecd.org/globalrelations/Skills_Gap_Assessment_Ukraine_UKR.pdf.

12.Official site of the Federation of Employers of Ukraine. Available at: http://fru.ua/ua/events/dualnavyshcha-osvita-v-ukraini-iak-zastosuvaty-dosvid-nimechchyny.

13.Slobodian, A., Stadnyi, Ye. (2016). Ukrainian students abroad: how many and why. Available at: https://cedos.org.ua/uk/osvita/ukrainski-studenty-za-kordonom-skilky-ta-chomu.

14. The Dual Education Concept for Educational Institutions in Ukriane. Available at: http://mon.gov.ua/usinovivni/povidomlennya/2017/11/21/v-rozdili-gromadske-obgovorennya-rozmishheno-proektkonczepcziyi-pidgotovki-faxivcziv-za-dual/.

15.The Law of Ukraine "On Education". Available at: http://w1.c1.rada.gov.ua/.

16.Tremblay, Diane-Gabrielle, Le Bot, Irène (2003). German system of dual training: analysis of evolution and modern challenges. Available at: https://www.teluq.uquebec.ca/chaireecosavoir/pdf/NRC03-04A.pdf. 